\title{
Purulent pericarditis
}

\author{
N SINZOBAHAMVYA AND M O IKEOGU \\ Department of Cardiothoracic Surgery and Department of Paediatrics, Mpilo Central Hospital, Bulawayo, \\ Zimbabwe
}

SUMmARY Eleven children under 16 years of age with purulent pericarditis were seen in one hospital in one year. The condition was always secondary to a septic focus elsewhere, usually staphylococcal pneumonia; its incidence after pneumonia was $0.64 \%$, but this may be an underestimate. Clinical diagnosis can be difficult in patients with pneumonia as the heart is not always enlarged. Persistent or progressive liver enlargement was an important diagnostic feature. The presence of excess pericardial fluid was easily confirmed by echocardiography. Early diagnosis and drainage followed by continuous irrigation with $0 \cdot 1 \%$ povidone iodine solution usually resulted in rapid recovery, but two patients died.

Purulent pericarditis continues to pose such diagnostic problems that most cases are diagnosed at necropsy. ${ }^{1}$ As few necropsies are carried out in African Hospitals its real incidence is difficult to estimate. Bacterial infections, particularly pneumonia, are more common in developing than in industrialised countries, and so purulent pericarditis might be expected to be a more common disease.

Recently several workers have reported that the best treatment for purulent pericarditis is to use appropriate antibiotics and surgical drainage as soon as the diagnosis has been made. ${ }^{2-7}$ Early aggressive treatment has reduced the mortality, which after medical treatment with antibiotics and pericardiocentesis is $43-100 \% .{ }^{89}$ The purpose of this study was to analyse the presentation, aetiology, management, and outcome in 11 children with purulent pericarditis treated in this hospital during 1985.

\section{Patients and methods}

Eleven patients aged from 5 months to 15 years were admitted to this hospital with acute feverish illnesses complicated by purulent pericarditis. Table 1 shows the clinical presentations and Table 2 the aetiology, management, and outcome. Pericardial disease was initially suspected when the fever did not resolve and cardiac tamponade developed. Persistent or progressive liver enlargement, often unresponsive to diuretics, was found to be an important sign. Three patients underwent diagnostic pericardiocentesis, and five underwent echocardiography, which showed excessive pericardial fluid. One patient had both echocardiography and a diagnostic pericardial tap. Two cases presented with unequivocal evidence of acute bacterial pericarditis with tamponade so drainage was undertaken immediately without further investigations.

All the children had subxiphoid pericardiostomies, seven under local anaesthesia and four under general anaesthesia with halothane or ketamine. The technique is simple and common..$^{5-61011} \mathrm{~A}$ piece of pericardium was sent for histological examination and a sample of pericardial fluid for culture.

Irrigation was carried out in eight cases. A wide bore drain, either a three way Foley catheter or a nasogastric tube cannulated with a second catheter to allow continuous irrigation, was placed in the pericardium, connected to an underwater seal, and allowed to drain by gravity. No suction was used. The cavity was irrigated with a solution of $10 \mathrm{ml}$ of $10 \%$ povidone iodine in one litre of $0.9 \%$ saline at the rate of $40 \mathrm{ml} / \mathrm{h}$; this was continued until the effluent was clear. The drain was removed 24 hours after irrigation was stopped. Postoperatively antibiotics were continued in all cases, the choice of drug depending on the bacteria cultured from the pericardial fluid.

\section{Results}

Bacteria were isolated from the pericardial fluid in eight cases; the fluid looked purulent in the remaining three but was sterile on culture. In two of these children other findings suggested tuberculosis, and in the third (case 5) the result could have been due to prolonged treatment with several antibiotics for 
Table 1 Clinical presentation of purulent pericarditis in children

\begin{tabular}{|c|c|c|c|c|c|c|c|c|c|c|}
\hline \multirow{2}{*}{$\begin{array}{l}\text { Case } \\
\text { No }\end{array}$} & \multirow[t]{2}{*}{ Age } & \multirow[t]{2}{*}{ Sex } & \multirow{2}{*}{$\begin{array}{l}\text { Diagnosis } \\
\text { on } \\
\text { admission }\end{array}$} & \multicolumn{5}{|c|}{ Signs of pericardial disease } & \multicolumn{2}{|c|}{ Pericardial fluid shown by: } \\
\hline & & & & Fever & $\begin{array}{l}\text { Percardial } \\
\text { rub }\end{array}$ & Hepatomegaly & Cardiomegaly & $\begin{array}{l}\text { Distended } \\
\text { neck veins }\end{array}$ & $\begin{array}{l}\text { Pericardial } \\
\text { tap }\end{array}$ & $\begin{array}{l}\text { Echo- } \\
\text { cardiogram }\end{array}$ \\
\hline 1 & 5 months & $\mathbf{M}$ & Pneumonia meningitis & + & - & + & + & + & ND & + \\
\hline 2 & 7 months & $\mathbf{M}$ & Kwashiorkor, pneumonia & - & $?$ & + & + & $?$ & + & ND \\
\hline 3 & 15 months & $\mathrm{F}$ & Pneumonia, heart failure & + & - & + & + & + & ND & + \\
\hline 4 & 2 years & $\mathbf{M}$ & Pneumonia & - & $?$ & + & - & + & ND & + \\
\hline 6 & $21 / 2$ years & $\mathbf{M}$ & Pncumonia after measles & + & $?$ & + & + & $?$ & ND & + \\
\hline 7 & 9 years & $\mathbf{M}$ & Pneumonia & + & $?$ & + & - & $?$ & + & ND \\
\hline 8 & 10 years & $\mathbf{M}$ & Osteomyelitis & - & + & + & + & + & ND & ND \\
\hline 9 & 11 years & $\mathrm{M}$ & Arthritis osteomyclitis & - & + & + & - & + & + & + \\
\hline 10 & 12 years & $\mathbf{M}$ & Meningitis, osteomyelitis & - & - & + & + & + & + & ND \\
\hline 11 & 15 years & M & Pneumonia & - & - & + & + & + & ND & ND \\
\hline \multicolumn{11}{|l|}{ Total } \\
\hline 11 & & \multicolumn{2}{|c|}{$2 \mathrm{~F}, 9 \mathrm{M}$} & $5(45 \%)$ & $2(18 \%)$ & $11(100 \%)$ & $7(64 \%)$ & $7(64 \%)$ & $4(36 \%)$ & $6(55 \%)$ \\
\hline
\end{tabular}

$+=$ Present: $-=$ not present; ?=not known: ND=not done.

fever of unknown origin: Kawasaki disease was also suspected. Table I shows the diagnosis in each case on admission; seven patients had pneumonia and three osteomyelitis. They were all febrile and were started on combinations of antibiotics for the primary illness.

The postoperative result was satisfactory in seven cases, with resolution of the clinical signs in an average of five days. One child (case 2) sustained a low grade fever until antituberculosis treatment was started, after which he improved rapidly. One patient (case 6) developed fever with enlargement of the liver two weeks after the initial pericardiostomy, and an echocardiogram showed reaccumulation of the pericardial fluid; this was drained with good effect. There were two deaths of which only one could be attributed directly to the pericarditis. One patient (case 4) died of severe bilateral pneumonia, and at necropsy there was no evidence that pericardial pus or effusion had reaccummulated. The second death (case 3 ) was due to delay in diagnosing the pericarditis.

\section{Discussion}

In previous reports of purulent pericarditis in African children pneumonia and osteomyelitis were the commonest associated diseases ${ }^{5-14}$ and Staphylococcus aureus the commonest causative organism. When pericarditis is associated with osteomyelitis diagnosis is fairly easy as it is indicated by dyspnoea and heart failure. Severe pneumonia with cardiac failure, on the other hand, may mimic cardiac tamponade, so pericarditis should always be suspected in any patient with pneumonia and heart failure. Echocardiography is useful and should be performed as soon as possible. When it is not available, however, diagnostic pericardiocentesis should be done when the clinical findings (fever, hepatomegaly, and distended neck veins) suggest that pericardial fluid has accumulated. Cardiomegaly may not always be present, and pericardial friction rub is infrequent. In our series hepatomegaly during the course of pyogenic infections was an important sign, particularly when fever failed to settle with appropriate antibiotic treatment.

In 1985,943 out of the 3754 children under 12 years old admitted to the paediatric department of this hospital had pneumonia. Six of these also had purulent pericarditis, an incidence of $0.64 \%$ of those with pnuemonia. The true incidence is probably higher, as necropsies were not always performed in children dying from heart failure secondary to pneumonia. In 1985 mortality from pneumonia was $5.5 \%$ and no case of purulent pericarditis was diagnosed at necropsy. Hospital records were available from 1979 onwards, and during 1979-84 only five cases of purulent pericarditis were recorded in children. None of these five survived, and in only one case was the diagnosis made before death. In the first six months of 1986 four new cases were diagnosed, in addition to the 11 reported here in 1985, and all four were successfully treated.

The present series of 11 cases is the largest seen in one African hospital in such a short time and may indicate that the disease is more common than is generally recognised. This fairly large number of cases is probably due to our awareness that purulent pericarditis is a complication in children with infection elsewhere and to the availability of echocardiography.

In recent years early surgical drainage has caused the mortality from purulent pericarditis to drop to between 0 and 28\%.6 101516 Pericardiectomy and 


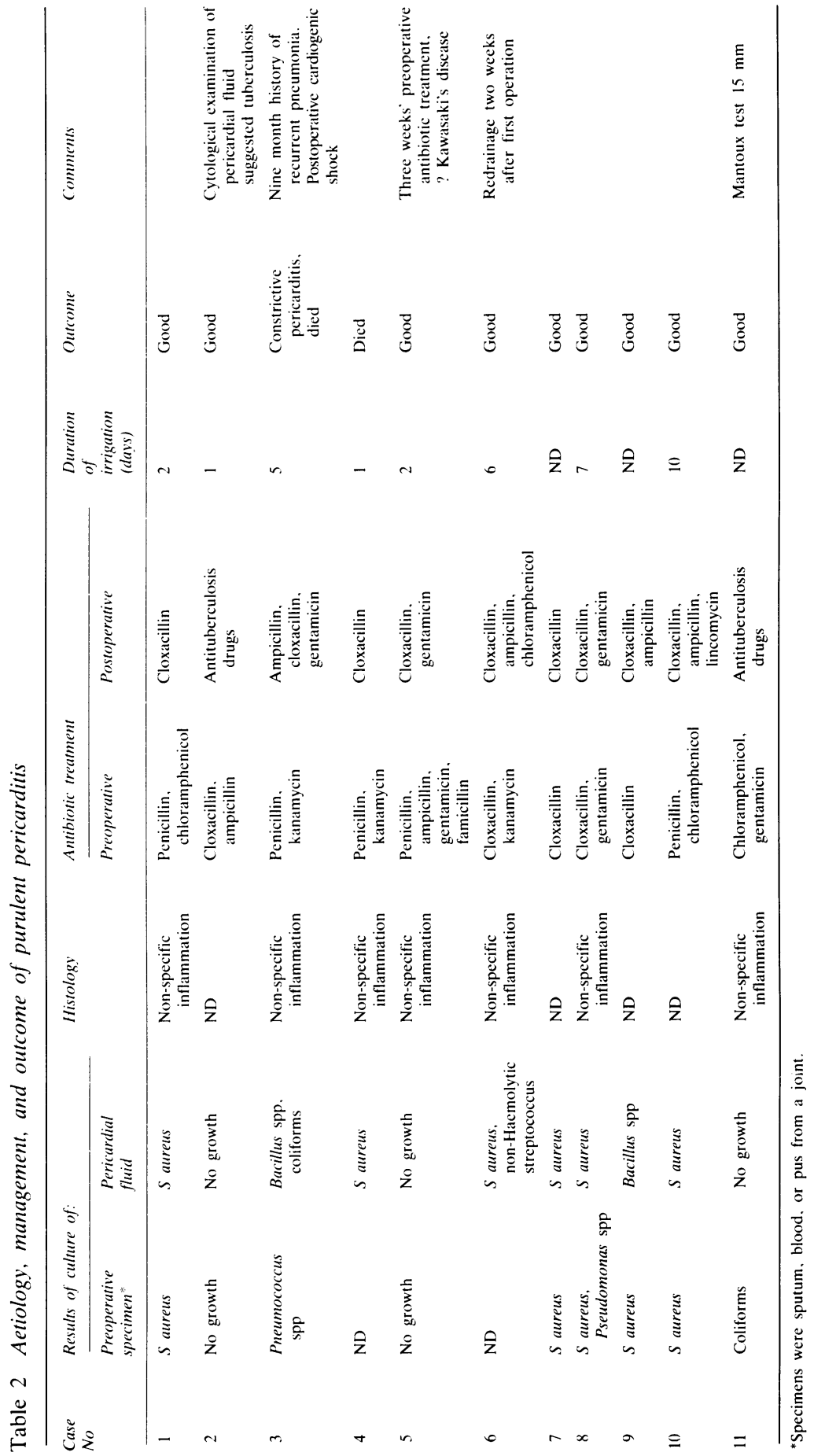

흘

$\overrightarrow{\vec{B}}$

응

$\frac{\bar{\sigma}}{\overline{0}}$

i

$\vec{\circ}$

$\vec{\omega}$

응

ํำ

बे

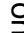

气

$\vec{Ð}$

뭉

응

용 
pericardiostomy (pericardiotomy, pericardial window) have both been used to drain the pus; whether pericardiostomy prevents the subsequent development of constrictive pericarditis is not certain, ${ }^{17}$ but constrictive pericarditis after pericardiectomy should be rare. ${ }^{16}$ Reports from several workers ${ }^{5}{ }^{10}$ bear out our experience that early pericardiostomy with a wide bore tube to allow free drainage is effective in preventing constriction. Both techniques, however, carry a small risk of late constrictive pericarditis. None of the survivors in our series developed constriction, which usually occurs in the first postoperative year. We consider that subxiphoid pericardiostomy is preferable because it is easy and can be done quickly under local anaesthesia. If a wide bore tube is not available continuous irrigation will prevent obstruction of the tube with pus and facilitate drainage; we irrigated most of our cases despite using a wide bore tube. Driscoll et al reported one case in which they irrigated with povidone iodine with no adverse effects. ${ }^{18}$ We used this solution in eight of our patients with no complications attributable to it. We consider that the use of povidone iodine, coupled with the irrigation, contributed much to the rapid recovery in our patients. Irrigation is particularly important as the pus is often too thick to flow freely through the drainage tube.

We conclude that in Africa $S$ aureus originating from a focus of pneumonia or osteomyelitis is a common cause of purulent pericarditis. We consider early subxiphoid pericardiostomy under local anaesthesia with continuous irrigation to be the treatment of choice in children with purulent pericarditis particularly when an anaesthetist and intensive care facilities are not available. Purulent pericarditis is more common than usually appreciated and when inadequately treated may account for an appreciable number of cases of so called idiopathic constrictive pericarditis. $^{12}$

\section{References}

' Klacsmann PG, Bulkley BH, Hutchins GM. The changed spectrum of purulent pericarditis. An 86 year autopsy experience in 200 patients. Am J Med 1977;63:666-73.

2 Stroobant J, Lcanage R. Deanficld J. Taylor JFN. Acute infective pericarditis in infancy. Arch Dis Child 1982:57:73-4.

${ }^{3}$ Corachan M. Poore P. Hadlcy GP. Tanner A. Purulent pericarditis in Papau New Guinca: report of 12 cases and review of the literature in a tropical enviroment. Trans $R$ Soc Trop Med Hyg 1983:77:341-3.

+ Lawric J. Tropical pericarditis. Trans R Soc Trop Med Hyg 1983:77:880.

5 Adebo OA. Adebonojo SA. Purulent pericarditis in children. J Thorac Cardiovasc Surg 1984:88:312-3.

${ }^{6}$ Garvin PJ, Danis RK, Lewis JE. Vallec JR. Willmann L. Purulent pericarditis in children. Surgery 1978:84:471-5.

${ }^{7}$ Feldman WE. Bacterial actiology and mortality of purulent pericarditis in pacdiatric paticnts. Review of 162 cases. Am J Dis Child 1979;133:641-4.

` Van Reken D. Strauss A. Hernandez A. Feigin RD. Infectious pericarditis in children. J Pediatr 1974:85:165-9.

" Mynors JM. Reichman B. Pericarditis. A five year study in the African. Cent Afr J Med 1973:19:19-22.

11' Wyler F, Knüsli D, Rutishauser M, Stocker F. Weber J, Real F. Pericarditis purulenta in children. Helv Paediatr Acta 1977:32:135-40.

"Levin BH, Aaron BL. The subxiphoid pericardial window. Surg Gynecol Obstet 1982:155:8(14-6.

12 D'Arbella PG, Patel AK, Grigg GL, Somers K. Pericarditis with particular emphasis on pyogenic pericarditis: A Uganda experience. East Afr Med J 1972;49:803-16.

1.3 Cameron EWJ. Surgical management of staphylococcal pericarditis. Thorax 1975;30:678-81.

it Weir EK, Joffe HS. Purulent pericarditis in children: an analysis of 28 cascs. Thorax 1977:32:438-43.

15 Mabogunjc OA, Adesanya CO. Khwaja MS, Lawric JH. Edington GM. Surgical management of pericarditis in Zaria. Nigeria. Thorax 1981:36:590-5.

16 Morgan RJ, Stephenson LW, Woolf PK, Edic RN, Edmunds LH. Surgical treatment of purulent pericarditis in children. J Thorac Cardiovasc Surg 1983;85:527-31.

17 Driscoll DJ, Rhodes KH. Treatment of purulent pericarditis - a comment. J Thorac Cardiovasc Surg 1983;85:531.

is Driscoll DJ, Rhodes KH. Purulent pericarditis. J Thorac Cardiovasc Surg 1984;87:641-2.

Correspondence and requests for reprints to Dr M O Ikeogu. Mpilo Central Hospital, Bulawayo, Zimbabwe.

Received 29 January 1987 